Doctor of Sciences (Technical Sciences), Professor, Academician of the National Academy of Educational Sciences of Ukraine, Rector of Mykolaiv V. O. Sukhomlynsky National University, 24 Nikolska Str, 54030 Mykolaiv, Ukraine, office@mdu.edu.ua

Oksana Oleksiuk

ORCID iD 0000-0002-5527-3861

PhD (Pedagogy), Associate Professor, Associate Professor of Pedagogy and Inclusive Education Chair, Mykolaiv V. O. Sukhomlynsky National University, 24 Nikolska Str, 54030 Mykolaiv, Ukraine, oleksjukoksana@ukr.net

\title{
PATRIOTIC EDUCATION OF STUDENTS IN TEACHING PSYCHOLOGICAL AND PEDAGOGICAL DISCIPLINE (ON EXAMPLE OF CRITICAL THINKING TECHNOLOGY)
}

The article deals with the problem of formation of university students during the teaching of the psychological and pedagogical disciplines not only the qualities of the patriot of their country, but also the formation of a person who must meet the requirements for the personality of the patriot leader. Examples of «Leader - Thought Thinking», «Synkveyn», «Press» methods during the teaching of psychological and pedagogical disciplines are given. The analysis of the students tasks implementation of the «Press» method is conducted in accordance with the determined components of the process of patriotic education: cognitive, motivational-value, activity-behavioural, personally-estimated and socially-valued. The following analysis of the essential characteristic of student answers is outlined as a challenge for further scientific developments.

Key words: citizen; components of the process of patriotic education; leader; method of development of critical thinking; patriotism; patriot leader.

https://doi.org/10.28925/1609-8595.2019.2.4145

Introduction. In educational sphere of the university, the whole process of training specialists in any field of activity is based on the consideration of the requirements for the qualifications and competences that university graduates have to possess. The Concept of the New Ukrainian School identified certain components of a graduate model of a comprehensive institution. One of these components is patriotism.

Since there are teachers in raising students' patriotic feelings, it is undeniable that modern specialists in the educational sphere themselves must meet the same requirements, that is to have developed patriotic feelings.

National patriotic education is the upbringing of the most important spiritual, moral, cultural and historical values that reflect the specifics of the formation and development of our society and state, national consciousness, lifestyle, world outlook and the fate of Ukrainians. It includes: infinite love and devotion to the homeland, pride for belonging to the people and his accomplishments, the reverence of national shrines and symbols, the willingness to decent and selfless service to society and the state (Budak, 2017, p. 212).
The analysis of scientific research, the current state of social life, the course of political events taking place in the country, shows that it is currently not enough to educate patriotically minded young people. It is necessary to simultaneously form the patriotic components of the personality of a future specialist, taking into account the needs of society regarding the civil obligations of the national elite - to be prepared to show leadership qualities and at any time to stand up for the sovereignty of their country.

The purpose of the article is to show the educational possibilities of some methods of critical thinking during the teaching of psychological and pedagogical disciplines.

Contemporary views of scholars at the problem of forming a personality of a leader-patriot. Among modern scientists who considered the components of patriotic education and personal qualities of the person - I. Bech, M. Boryshevskyi, P. Verbytska, M. Yevtukh, I. Zyazun, P. Ignatenko, V. Kremen, S. Maksymenko, A. Pogribnyi, Yu. Rudenko, O. Savchenko, K. Chorna, L. Chupriy, O. Shestopalyuk, P. Shcherban, and others.

The national-patriotic upbringing is sufficiently researched in modern pedagogical science (Y. Bondarenko, M. Boryshevskyi, O. Vishnevskyi, R. Zakharchenko, 
V. Kuz, B. Tsymbalistyi, V. Yaniv, Y. Yarema, O. Yarmolenko) and military- patriotic upbringing (M. Zubaliy, V. Ivashkovskyi). But scientific studies on the formation of the qualities of the patriot leader among the student youth are not considered by the scientists to a sufficient degree, which also predetermined the choice of the direction of scientific research.

The purpose of patriotic education is the formation of a patriot citizen of Ukraine who is ready to independently build the state and ensure its national security, to know its rights and responsibilities, to defend its civilized rights, to promote the unification of the Ukrainian people, civil peace and harmony in society, to be competitive, to successfully realize itself in a society as a citizen, a family man, a professional, a carrier of Ukrainian national culture (The Concept of national-patriotic education of youth, 2015).

Foreign scientific researchers emphasize that «in today's world, institutions of higher education, which provide opportunities for the development of the leadership potential of their students, are of great importance in the preparation of future leaders» (Christensen, 2019, p. 5).

A special role in the process of formation of a patriot leader is given to teachers of social and humanitarian disciplines of institutions of higher education. It is their creative skill that promotes the development of professionally important qualities of students, including the qualities that are important for the further development of the country, namely, the qualities of the patriot leader.

According to Zh. Petrochko (2018), one of the general indicators of the effectiveness of carrying out activities on national patriotic education is the number of trained leaders of activists who are ready to identify and implement initiatives of national patriotic education.

The outlined problem set requirements for the updating of the forms, technologies, methods of training of the modern teacher of different parts of education. The search for creative new approaches to the introduction of ideas for the formation of the qualities of the patriot as a student among students led to an appeal to the technology of developing critical thinking and the selection of some characteristic methods, such as method Press, letterthinking method, Synkveyn method, essay, etc.

Practical use of the methods of critical thinking in teaching psychological-pedagogical subjects. So, during the teaching of the discipline «Pedagogy» students are given the task of making a small speech, meeting with the children of the preschool educational institution / pupils of the junior class, etc., to a certain holiday (the Day of Unity and Freedom of Ukraine, the Day of the memory of the heroes of Kruty, Day of the Defender of Ukraine, the Day of the Armed men forces of Ukraine, etc.). This task helps students to improve the art of eloquence, has a patriotic orientation and forms the ability to keep the audience's attention.

While teaching the special course «Youth Preparation for Family Life and Responsible Parenthood», a discussion is held on the topics of the technology of formation of a patriot leader in the family, patriotic education in the family, the formation of patriotic feelings and leadership qualities in preschool and junior children, helping in the development of skills to convince others. Given that patriotic education begins with a small homeland, that is, a family, in May, as part of the celebration of the Day of the Family students were given the task - to write a Letter to the mother / father (or other person who performed their functions) with words of gratitude to them address and read this letter to the parents. Students took this task very positively, agreeing with a teacher who spoke very good words to their parents, did not communicate with them, taking due care of their care for their children.

The positive influence on the formation of the personality of the patriot leader is provided by activities related to volunteer activities that allow developing responsibility, love and care for the outside world and people, to increase the patriotic spirit, as well as the level of moral and ethical values. Students receive this kind of task in the studied disciplines «Inclusive and Social Pedagogy».

During the teaching of the discipline «Psychology (general, child, pedagogical), students were offered a research task. According to the proposed teacher, a list of tests for each student was necessary to conduct a psychological study among the students of the academic group to identify certain features of the individual. Proposed tests should determine the level of development or the presence of the students the features and qualities that are inherent in the patriot leader. For example, the projective method «Me and my country» gave an idea of the student's vision of his place in the country, his position and the general impression of patriotic perception of the Motherland.

The next task was based on the consideration of the structure of personality in psychology. So, the Selfconcept of personality is revealed through the following components: cognitive or Self-image - the idea of their abilities, appearance, social status, etc.; emotional and appraisal - self-esteem, self-criticism, self-deprecation, self-love, etc. behavioural (volitional) - the desire to increase self-esteem, self-esteem, etc. In this, in psychology, there are several basic mechanisms for the development of self-consciousness of the individual, namely: identification (from the Latin identificare identification) - the process of identifying oneself with another individual or group based on stable emotional connection, inclusion in the inner world and acceptance as its own norms, values, patterns of behaviour; Reflection (from lat. reflexio - conversion back) - the process of self-knowledge by the subject of internal mental acts and states, as well as awareness of how the subject is perceived and evaluated by other people; empathy (from the Greek - empathy) - penetration into the experiences of another person, forms of which are empathy (experience of the subject of the same emotional states that another person feels) and compassion (the experience of their 
own emotional states about the feelings of another), etc. (Oleksyuk, 2017, p. 126).

Considering the theoretical positions, the refining tasks were introduced to known methods of critical thinking «Press», «Synkveyn», «Write a sentence». These methods have been proposed for students of the first year in the discipline «Psychology (general, child psychology, pedagogical)» as creative tasks on topics «Thinking» and «Imagination».

Thus, the task of the «Press» method helps to show a clear and reasoned position of a person on controversial issues of interest to researchers. The «Press» method has a standardized algorithm for sequential actions of the study, consisting of four stages:

1. Positions. I think that ... (express your opinion, explain your opinion).

2. Background. ... because ... (give the reason for the appearance of this idea, that is, on what evidence is there to support your opinion).

3. Example. ... for example ... (introduce facts that demonstrate your argument, they will strengthen your position).

4. Conclusions. Therefore, I believe ... (to summarize your opinion, conclude what needs to be done, that is, it is a call to agree with your opinion) (Bekh et al., 2015, p. 45).

Students were offered five statements: «I think the patriot is ...», «I think I can call myself a patriot, because ...», «I believe that patriotism manifests itself in ...», «I consider that the patriot must be ...», «I believe that a patriot-citizen can be called a person who ...». Each of these statements was formulated considering theoretical teachings on the theory of personality for a certain component of the process of patriotic education (see Table 1).

\section{The ratio of components of the process of patriotic education} and sayings for the «Press» method

\begin{tabular}{|l|l|}
\hline \multicolumn{1}{|c|}{ Components of the process of patriotic education } & \multicolumn{1}{c|}{ Statement for the «Press» method } \\
\hline Cognitive component & I think the patriot is ... \\
\hline Motivational-value component & I think that a patriot needs to be ... \\
\hline Activity-behavioural component & I think patriotism manifests itself in ... \\
\hline Personality and evaluation component & I think I can call myself a patriot, because ... \\
\hline Socially-valued component & I believe that a patriot-citizen can be called a person who ... \\
\hline
\end{tabular}

Students had to choose only three of the statements and reasonably prove their understanding of the topic. Selection by students of certain statements showed the priority of the components of the process of patriotic education, which were determined by us, taking into account the psychological interpretation of the concept of personality.
The analysis of the results of the research using the «Press» method showed (see Table 2) that $85.7 \%$ of students firstly (average grade - 1.35) chose «I believe the patriot is...» i.e., indicating indirectly the cognitive component of the process of patriotic education of the student young people.

Table 2

Range of statements chosen by students for argumentation of their position in method «Press»

\begin{tabular}{|c|l|c|c|}
\hline № & \multicolumn{1}{|c|}{ Assertion } & $\begin{array}{c}\% \\
\text { of the respondents }\end{array}$ & $\begin{array}{c}\text { Average rank } \\
\text { of choice }\end{array}$ \\
\hline 1. & I think the patriot is... & $85,7 \%$ & 1,35 \\
\hline 2. & I think patriotism manifests itself in... & $71,4 \%$ & 2,06 \\
\hline 3. & I think that a patriot needs to be... & $48,6 \%$ & 2,54 \\
\hline 4. & I think I can call myself a patriot, because ... & $48,6 \%$ & 2,13 \\
\hline 5. & I believe that a patriot-citizen can be called a person who... & $45,7 \%$ & 2,05 \\
\hline
\end{tabular}

The second number of elections is the statement «I believe that patriotism manifests itself in...». He was chosen by $71.4 \%$ of students to substantiate their position, while pointing at the activity-behavioural component. The rank of this position is 2.06 .

If we round up to the tenth by the rules of mathematics, then we have to put a rank -2.1 , which will be identical with the two following ranks, if they are also rounded up to the tenth. Therefore, in order to see a clearer picture of the research, we will leave the results of the average rank to one hundredths.

It should be noted that the following two positions have the same number of elections, namely $48.6 \%$. This is the statement «I believe that I can call myself a patriot, because...», which has an average rank of 2.13, and defines the personality and value component of the process of patriotic education of student youth. The second statement - «I believe that the patriot must be...», whose average rank is 2.54 , and indicates the motivational-value component.

Interesting is the fact that the smallest student election fell on the statement «I believe that a patriot-citizen can be called a person who...» - only $45.7 \%$, but the average grade is 2.05 , indicating the second on rank place. This statement describes the socially-valued component in our study.

Conclusions. An analysis of only one of the techniques used in the development of critical thinking, namely the «Press» method, has shown the possibility of conducting educational elements of educational impact on students in the course of the educational process in order to form the qualities of the patriot leader through their awareness of their role for the future of the country. 
Prospects for further research. The results presented in this article only partially show an understanding of the concept of patriotism and the attitude of student youth to its components. Further consideration of students' responses to each of the four stages of the «Press» method makes it possible to generalize the essential component of each of the components and make a cluster analysis.

\title{
References
}

Budak, V. D. (2016). Viyskovo-patriotichne vihovannya yak skladova natsionalno-patriotichnogo vihovannya molodi [Militaru-patriotic education as a component of national-patriotic education of youth]. Naukoviy visnik Mikolayizskogo natsionalnogo universitetu imeni V. O. Suhomlinskogo. Pedagogichni nauki, 4 (55), 212-215 (ukr).

Bekh, I. D., Kyrychenko, V. I. , Petrochko, Zh. V. (2015). Z Ukrayinoyu v serci (trening z patriotychnogo vykhovannya ditej ta molodi) [With Ukraine in the heart (training in patriotic education of children and youth]. Kyiv, Ukraine: Instytut obdarovanoyi dytyny NAPN Ukrayiny (ukr).

Koncepciya nacionalno-patriotychnogo vykhovannya molodi (dodatok 2 do nakazu Ministerstva osvity i nauky Ukrayiny vid 16.06.2015 r. № 641) [Conception of national-patriotic education of youth] (2015). Informacijnyj zbirnyk ta komentari Ministerstva osvity i nauky Ukrayiny, 8, 87-95 (ukr).

Oleksyuk, O. Ye. (2017). Psykholohiia zahalna. Kurs lektsii. Navchalno-metodychnyi posibnyk [General psychology. Course of lectures. Textbook]. Mykolaiv, Ukraine: Ilion (ukr).

Christensen, M. K. (2019). Preparing students for leadership: the role of universities. Continuing Professional Education: Theory and Practice, 1 (58), 5-10. DOI: https://doi.org/10.28925/1609-8595.2019.1.510 (eng).

Petrochko, Zh. (2018). National and patriotic education of children and youth: questions of standards and indicators. Education: Modern Discourses, 1, 200-206. DOI: https://doi.org/10.32405/2617-3107-2018-1-20 (eng.)

\section{Література}

Будак В. Д. Військово-патріотичне виховання як складова національно-патріотичного виховання молоді. Науковий вісник Миколаївського національного університету імені В. О. Сухомлинського. Педагогічні науки. 2016. № 4 (55). С. 212-215.

Бех І. Д., Кириченко В. І., Петрочко Ж. В. 3 Україною в серці (тренінг з патріотичного виховання дітей та молоді). Київ: Інститут обдарованої дитини НАПН України, 2015. 186 с.

Концепція національно-патріотичного виховання молоді (додаток 2 до наказу Міністерства освіти і науки України від 16.06.2015 р. № 641). Інформачійний збірник та коментарі Міністерства освіти і науки України. 2015. № 8. C. $87-95$.

Олексюк О. Є. Психологія загальна. Курс лекцій. Навчально-методичний посібник. Миколаїв: Іліон, 2017. $392 \mathrm{c}$.

Christensen M. K. Preparing students for leadership: the role of universities. Неперервна професійна освіта: теорія і практика. 2019. № 1 (58). C. 5-10. DOI: https://doi.org/10.28925/1609-8595.2019.1.510.

Petrochko Zh. National and patriotic education of children and youth: questions of standards and indicators. Education: Modern Discourses. 2018. № 1. C. 200-206. DOI: https://doi.org/10.32405/2617-3107-2018-1-20.

\section{ПАТРІОТИЧНЕ ВИХОВАННЯ СТУДЕНТІВ У ВИКЛАДАННІ ПСИХОЛОГО-ПЕДАГОГІЧНИХ ДИСЦИПЛІН (НА ПРИКЛАДІ ТЕХНОЛОГІЇ КРИТИЧНОГО МИСЛЕННЯ)}

\author{
Будак Валерій, доктор технічних наук, професор, \\ академік Національної академії педагогічних наук України, \\ ректор Миколаївського національного університету імені В. О. Сухомлинського, \\ вул. Нікольська, 24, 54030 Миколаїв, Україна, \\ office@mdu.edu.ua \\ Олексюк Оксана, кандидат педагогічних наук, доцент, \\ доцент кафедри педагогіки та інклюзивної освіти, \\ Миколаївський національний університет імені В. О. Сухомлинського, \\ вул. Нікольська, 24, 54030 Миколаїв, Україна, \\ oleksjukoksana@ukr.net
}

Стаття присвячена проблемі формування у студентів університету під час викладання дисииплін психолого-педагогічного ииклу не тільки якостей патріота своєї країни, а й формування особистості, яка має відповідати вимогам, що ставляться до особистості лідера-патріота. Наводяться приклади використання методів технології розвитку критичного мислення «Лист-роздум», «Сінквейн», «Прес» під час викладання психолого-педагогічних дисциплін. Показано, як виконання завдання методу «Прес» допомагає побачити чітку й аргументовану позицію людини з суперечливих проблемних тем, що иікавлять дослідників. Студентам 
запропонували п'ять висловлювань: «Я вважаю, патріот - ие..», «Я вважаю, що я можу називати себе патріотом, тому що..», «Я вважаю, що патріотизм проявляється у..», «Я вважаю, що патріотом необхідно бути...», «Я вважаю, що патріотом-громадянином можна назвати людину, яка...». Кожне із цих висловлювань були сформульовані з урахуванням теоретичних викладок з теорї особистості під певний компонент процесу патріотичного виховання: когнітивний, мотиваційно-ціннісний, діяльнісно-поведінковий, особистіснооцінний та суспільно-оцінний. Проведений аналіз виконання студентами завдань методу «Прес» відповідно до обумовлених компонентів прочесу патріотичного виховання показав, що на перше місце за кількістю виборів та рангу вийшов когнітивно-пізнавальний компонент. Друге місце за кількістю виборів та третє місце за рангом займає діяльнісно-поведінковий компонент. Два компоненти - мотиваційно-ціннісний та особистісно-оцінний - мають однаку кількість виборів. За рангом же передує мотиваційно-ціннісний компонент. Наступний аналіз сутнісної характеристики відповідей студентів окреслені як завдання подальших наукових розробок.

Ключові слова: громадянин; лідер; лідер-патріот; метод розвитку критичного мислення; патріотизм; складові компоненти процесу патріотичного виховання.

\title{
ПАТРИОТИЧЕСКОЕ ВОСПИТАНИЕ СТУДЕНТОВ ПРИ ПРЕПОДАВАНИИ ПСИХОЛОГО- ПЕДАГОГИЧЕСКИХ ДИСЦИПЛИН (НА ПРИМЕРЕ ТЕХНОЛОГИИ КРИТИЧЕСКОГО МЫШЛЕНИЯ)
}

\author{
Валерий Будак, доктор технических наук, профессор, \\ академик Национальной академии педагогических наук Украины, \\ ректор Николаевского национального университета имени В. А. Сухомлинского, \\ ул. Никольская, 24, 54030 Николаев, Украина, \\ office@mdu.edu.ua \\ Олексюк Оксана, кандидат педагогических наук, доцент, \\ доцент кафедры педагогики и инклюзивного образования, \\ Николаевский национальный университет имени В. А. Сухомлинского, \\ ул. Никольская, 24, 54030 Николаев, Украина, \\ oleksjukoksana@ukr.net
}

В статье поднимается проблема формирования у студентов университета во время преподавания дисциплин психолого-педагогического цикла не только качеств патриота своей страны, а и формирование личности, которая должна отвечать требованиям, которые ставятся к личности лидера-патриота. Приводятся примеры использования методов технологии развития критического мышления «Письмо-размышление», «Синквейн», «Пресс» во время преподавания психолого-педагогических дисциплин. Проводится анализ выполнения студентами заданийметода «Пресс» соответственно кобусловленным компонентам процесса патриотического воспитания: когнитивного, мотивационно-ценностного, деятельностно-поведенческого, личностно-оценочного, общественно-оценочного. Последующий анализ содержательной характеристики ответов студентов намечень как задания последующих научных разработок.

Ключевые слова:гражданин; лидер; лидер-патриот; метод развитиякритическогомыцления; патриотизм, составляющие компоненты прочесса патриотического воспитания.

Стаття надійшла до редакиї 15.05.2019

Прийнято до друку 13.06.2019 